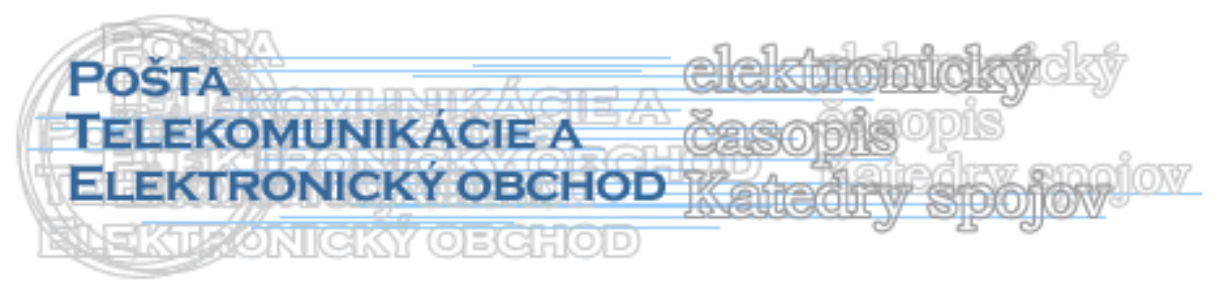

\title{
ATRIBÚTY ÚSPEŠNEJ VIRÁLNEJ SPRÁVY URČENEJ PRE ŠTUDENTOV
}

\section{Petra Hollá Bachanová*}

\begin{abstract}
The article is dedicated to the issue of viral marketing. Describes its historical development, its different types and evaluate its positive and negative aspects. The aim of this paper is based on a survey to identify the attributes of a successful viral messages designated for students.
\end{abstract}

Keywords: viral marketing, marketing, Word-of-mouth.

\section{1. Úvod}

Aj napriek tomu, že sa pojem virálny marketing začal používat' len nedávno, jeho podstata fungovania bola známa dávno, ešte pred vznikom internetu. Túto formu marketingu medzi prvými spomenul Frank Bass, v roku 1969, vo svojom článku v časopise Management Science, kde sa prvýkrát zmienil o jeho princípoch. Za prvý príklad jeho uplatnenia je považovaný e-mail zaslaný v roku 1978 spoločnost'ou DEC (dnes Hewlett Packard), všetkým l'udom na západnom pobreží USA, ktorí mali vlastnú ARPANET adresu. E-mail obsahoval inzerciu nového výrobku DEC-20. Prvýkrát sa však pojem vírusový marketing objavil v roku 1994 v knihe Douglasa Rushkoffa - Media Virus. O autorstvo by sa však mohol usilovat' aj profesor Jeffrey Rayport z Harvardu, ktorý ho vo svojom článku spomenul v roku 1996. Samo autorstvo termínu je v konečnom dôsledku pripisované Stevu Jurvetsonovi, generálnemu riaditel'ovi spoločnosti Draper Fischer Jurvetson, ktorý v roku 1997 pomenoval praktiky spoločnosti Hotmail. Hotmail bola nová služba určená pre používatel'ov internetu. Išlo o bezplatnú e-mailovú správu, ktorú vymysleli Sabeer Bhatia a Jack Smith. Taktika Hotmailu bola jednoduchá - na konci každej správy bol pridaný krátky text, ktorý vyzýval príjemcu aby si zaobstaral svoju vlastnú bezplatnú emailovú schránku prostredníctvom http://hotmail.com. Každí užívatel' tak spolu so správou zaslal aj krátky reklamný text, ktorý sa začal šírit' ako vírus po celom svete a Hotmail získal za polroka milióny užívatel'ov a tým aj obrovské zisky $\mathrm{z}$ reklamy a prvú pozíciu $\mathrm{v}$ histórii uplatnenia virálneho marketingu. Jiří Rýdl tvrdí, že skutočnou živnou pôdou pre rozširovanie virálneho marketingu boli až univerzitné siete v USA, prostredníctvom ktorých sa začali šírit’ rôzne spoty, vtipy a zábavné videá. [1,2,3]

\section{Teoretické vymedzenie problematiky}

Pojem „virálny“ je odvodený z anglického slova viral, čo znamená vírusový. V slovenskej literatúre sa objavujú dve formy tohto pojmu (synonymá) - virálny aj vírusový.

\footnotetext{
* Ing. Petra Hollá Bachanová, PhD., Žilinská univerzita v Žiline, Fakulta Prevádzky a ekonomiky dopravy a spojov, Katedra spojov, Univerzitná 1, 01026 Žilina. tel.: $041 / 5133118$

e-mail: Petra.Bachanová@fpedas.uniza.sk
} 
Často je označovaný ako d'alší stupeň prastarého Word-of-mouth marketingu. Táto forma marketingu je známa ako ústne podanie, teda informácia je prenášaná medzi l'ud'mi ústnou formou, v podobe pozitívnych alebo negatívnych skúseností s produktmi alebo službami. Virálny marketing však oproti Word-of-mouth marketingu, mení prenosový kanál, nakol'ko využíva masovo-komunikačné prostriedky, ktorými sú napr. internet alebo mobilné telefóny. Philip Kotler definuje virálny marketing ako invertovanú verziu marketingu z počutia. [4,5]

Př́ḱrylová a Jahodová interpretujú virálny marketing ako spôsob komunikácie, kedy sa správa s reklamným obsahom javí príjemcovi natol'ko zaujímavá, že ju samovol'ne šíri d’alej. Správa je tak exponenciálne šírená mediálnym priestorom bez kontroly iniciátora a možno ju prirovnat' $\mathrm{k}$ vírusovej epidémii. [6]

Seth Godin prirovnáva virálny marketing $\mathrm{k}$ ideavírusu, ktorý reprezentuje určitý marketingový nápad, ktorý sa hýbe, rastie a infikuje príjemcov. Tvrdí, že vd’aka médiám ako televízia a internet, ktoré zosilňujú odporúčania ovel’a väčšieho publika prostredníctvom interaktivity, sa stáva word-of-mouth mŕtvym, zatial čo idavírus naberá na sile. Godin dokonca označuje virálny marketing pojmom word-of-mouse (marketing šírený myšou), ktorý je umocnený silou on-line komunikácie a založený na profite $\mathrm{z}$ dobrovol'ného publikovania obsahu webu l'ud'mi, ktorí chcú takýto obsah zdiel'at'. Nie však každý ideavíarus je možné považovat' za virálny marketing. [7]

Neodmyslitel'nou súčast'ou virálneho marketingu je kreatívne riešenie správy, ktoré dokáže publikum správne oslovit' tak, aby sa chceli o ňu podelit'. Virálny obsah musí byt' pre publikum okamžite fascinujúci a obohacujúci, musí zaujat' originalitou, humorom či kontroverznost'ou. Prvým nositel'om takéhoto obsahu, ako už bolo vyššie spomenuté bol email. V súčasnosti sú to skôr virálne videá, videoklipy, animované hry či obrázky. Medzi najčastejšie virálne formáty patria customizované pohl'adnice a videá, microsites, synergie televíznej reklamy a microsites, logotyp v texte, diskusie, paródie na vlastné výrobky alebo služby, virálne videá a mashhupy. [8]

\section{Prínos a negatíva virálneho marketingu}

V poslednej dobe je možné zaznamenat' rastúcu nechut' l'udí k reklame ako takej. Tu vzniká priestor pre jej perspektívnu alternatívu, ktorá využíva siet’ový účinok internetu virány marketing. Virálna kampaň nemá definovaný koniec, ako je to pri klasickej reklamnej kampani a prostredníctvom dobrého cielenia, dokáže oslovit' vybrané skupiny l'udí pri nízkych nákladoch. Za výhody virálneho marketingu možno považovat':

- Nízke náklady a investície: optimalizácia zdrojov je $v$ dnešnej dobe témou číslo jedna. Virálny marketing poskytuje možnost' zasiahnut' vel'ký počet l'udí pri nízkych nákladoch.

- Posilnenie značky a image: značka propagovaná prostredníctvom virálnej správy l'udí neruší, nezat’ažuje, ale naopak prirodzeným a nenásilným spôsobom sa začlení do života príjemcu, bez vplyvu na jeho súkromie. Ponúka im interaktivitu, v rámci ktorej celý proces šírenia riadi sám recipient.

- Dobré cielenie aktivít: je vysoko pravdepodobné, že virálna správa zasiahne správnu ciel'ovú skupinu, nakol'ko sám šíritel' si je istý, že správu pošle niekomu, koho bude naozaj zaujímat' a ocení ju rovnako ako on.

- Udržiavanie a budovanie vzt'ahu so zákazníkmi: podnik sa prostredníctvom niektorých nástrojov virálneho marketingu, dokáže dostat' ovel'a bližšie k svojim existujúcim ako aj potenciálnym zákazníkom a získat' tak okamžitú spätnú väzbu.

- Získanie najaktuálnejších informácií o potrebách spotrebitel'ov: spotrebitelia často píšu na blogoch a fórach o tom, s čím sú nespokojní, aké nové potreby pocit’ujú a čo by potrebovali $\mathrm{k}$ tomu aby boli tieto potreby uspokojené. Podniku tak stačí tieto zdroje informácií sledovat'. 
Aj napriek množstvu výhod, ktoré virálny marketing poskytuje, je možné sa stretnút’aj s niekol'kými nevýhodami. Asi najväčšou nevýhodou je strata kontroly marketérov nad priebehom virálnej kampane. V niektorých prípadoch sa môže stat', že virálny obsah zmutuje a stane sa riskantný a deštruktívny, čím môže vážne poškodit' pôvodne úspešnú značku.

Spotrebitelia sa stali omnoho sebavedomejšími a náročnejšími ako v minulosti. Tvoria a editujú obsah webu, píšu komentáre, komunikujú cez sociálne siete. Jeden nespokojný zákazník, prípadne konkurenčná firma môžu jedným príspevkom narušit' dôveryhodnost' spoločnosti a naštrbit' jej imidž.

Ďalším rizikom je obt’ažovanie. Často sa stáva, že zákazník je zahltený množstvom podobných správ s rovnakou štruktúrou. Posolstvo firmy sa tak môže l'ahko stratit' medzi ostatnými, na oko rovnako vyzerajúcimi správami, ktoré l’udia dostávajú na dennej báze. Zákazník tak nevie, ktorej správe má venovat' pozornost' a správy tak často končia napr. v nevyžiadanej pošte, prípadne sú ignorované alebo odstránené.

Za nevýhodu možno považovat' aj pred tým výhodný buzz efekt. Dôvodom je fakt, že negatívna reklama sa šíri podstatne rýchlejšie ako tá pozitívna. Namiesto vytvárania pozitívneho buzz o firme sa môže virálny marketing prejavit’ aj opačným spôsobom. [9]

\section{Analýza súčasného stavu doma a v zahraničí}

Slovensko ešte stále v plnej sile nevyužíva potenciál virálneho marketingu, tak ako ho využívajú ostatné zahraničné štáty. Mnohí už však pochopili, že úlohou novodobej reklamy už nie je vyberat' si spotrebitel'ov, ktorých by chceli oslovit', ale vol'ba sa presúva na spotrebitel'ov, ktorí v dnešnej dobe rozhodujú o tom, ktorej reklame a značke dovolia aby si ich podmanila. $\mathrm{Na}$ druhej strane hrá v prospech virálneho marketingu aj fakt, že účinnejšia je reklama smerovaná nie od firmy k zákazníkovi, ale od zákazníka k zákazníkovi. Na to však musí byt' virálna správa dostatočne zaujímavá a inšpirujúca $\mathrm{k}$ šíreniu.

Najdôležitejším prvkom virálneho marketingu je obsah, ktorý nesie určité marketingové posolstvo a dá sa l'ahko šírit'. Príjemca by nemal robit' zložité a náročné úkony, ale len jednoducho kliknút' a tak preniest' odkaz na želanú adresu. Obsah musí mat' prvky charakteristické odlišnost'ou, vyniknutím, či mimoriadnym pritiahnutím pozornosti. Je jedno, či to spôsobí zábavný prvok, prísl'ub finančných ziskov alebo vzdelávacia hodnota.

Pretože marketing zostáva marketingom aj v on-line svete a jeho princípy a zákonitosti sa zmenou nástrojov nemenia, musí virálna správa poskytnút' záujemcovi hodnotu a firme musí byt' schopná priniest' finančnú návratnost'. V opačnom prípade môže byt' síce zaznamenaná vysoká šíritel'nost' správy, no len t’ažko by sa dalo hovorit' o profite z jej šírenia.

Vo všeobecnosti možno popísat' desat' pravidiel, ktorých by sme sa mali držat' pri vytváraní úspešnej virálnej správy:

- prirodzenost' (nenútenost' podania),

- ponúknut' niečo úžasné (príbeh o ktorý sa budú chciet’ príjemcovia delit'),

- robit' to pre používatel'a (postavit' ho do žiary reflektorov, aby sa cítil ako hviezda),

- kreativita, zábava, správny čas (nemalo by íst' len o zábavu v akomsi vákuu),

- jednoduchost' (l'ahko pochopitel'ný obsah),

- nenútit' l'udí do šírenia správy (nešlo by už o virál),

- trpezlivost' (správy sa môžu šírit' aj pomaly, dôležité je že sa šíria),

- vtipné osobnosti (známi l’udia),

- brainstorming (pre vytvorenie ničoho virálneho),

- vzt’ahy a reputácia by mali ovplyvňovat' stratégiu (virál odráža značku a stupeň sociálneho kapitálu firmy). 
Virálny marketing mnoho autorov delí na aktívny a pasívny. Rozdiel medzi nimi je zdroji úvodného podnetu. Pri aktívnej forme virálneho marketingu tento podnet vychádza zo strany firmy, ktorá sa snaží zvýšit' predaj a tým aj povedomie o firme, či samotnom produkte. Podnet smeruje k zákazníkom často za pomoci elektronickej pošty, telefonátu, či počítačovej siete. V prípade pasívneho virálneho marketingu samotná firma nezasahuje do šírenia informácie, pretože to nie je jej ciel'om. Skôr sa spolieha na pozitívne vyjadrenia zákazníkov a svoju snahu sústred'uje na vyvolanie pozitívnej reakcie prostredníctvom ponuky kvalitného produktu. [10]

Blake Rohrbacher v článku The Power of Viral Marketing popisuje d'alších pät' typov virálneho marketingu, z hl'adiska prístupu samotných užívatel'ov. Posledný z nich je označený za negatívnu formu.

- Value viral: šírenie skúseností s kvalitou produktu, na základe pozitívnej skúsenosti. Ako príklad je tu možné uviest' Hotmail, či knihy Harry Potter, Yahoo alebo Amazon. Tento typ virálu sa nedá vytvorit' cielene, produkt musí byt' dostatočne dobrý na to aby l'udia o ňom začali hovorit'.

- Guile viral: je založení na snahe "predat' sa“" a získat' osobnú odmenu. L’udia musia sami zhodnotit', či je odmena dostatočne dobrá za to, že riskujú nespokojnost' od ostatných. Tento typ kampane sa taktiež nedá umelo vytvorit'. Príkladom môže byt' taktika, kedy sú pôvodný zákazníci odmeňovaní za prinesenie zákazníkov nových.

- Vital viral: pri tejto forme l'udia šíria svoje skúsenosti, pretože chcú získat' rovnaký produkt, ktorý je dostatočne dobrý na to, aby urobili želanú akciu a presvedčili ňou aj ostatných. Táto forma virálu sa taktiež nedá umelo vytvorit'. Príkladom môže byt' ICQ, RealPlayer, Macromedia Flash, či eBay.

- Spiral viral: základom tejto formy virálu je fakt, že l'udia sa radi delia o vtipné, niekedy až „sprosté“ alebo zaujímavé skúsenosti (vtipy, hampster dance, superfriends video klip,...). Tento typ virálu taktiež nemožno umelo vytvorit'. Najúspešnejšie virály pôvodne neboli určené na virálne kampane, ale skôr len na pobavenie.

- Vile viral: predstavuje negatívnu formu virálneho marketingu, v rámci ktorého l’udia varujú iných pred negatívnou skúsenost’ou (napr. Apple newton, kniha Plan B, Olestra,...). Negatívne správy sa šíria omnoho rýchlejšie a vo väčšej miere ako správy pozitívne, čím môžu zásadne poškodit' povest' firmy. Na Slovensku sme sa mohli stretnút' s touto formou napr. pri kauze týkajúcej sa predaja konského mäsa deklarovaného ako hovädzie. [11]

Z mnohých prieskumov vyplýva, že l’udia najradšej šíria videá, ktoré sú najväčším šíritel'om atmosféry, nakol'ko sú komplexné a nie sú len obrazom ale aj zvukom. Dokážu zákazníkov strhnút' a vyprovokovat' $\mathrm{k}$ akcii. $\mathrm{O}$ náraste sledovanosti videí na internete hovorí aj americká štúdia Pew Research Center, ktorej sa zúčastnilo 1003 respondentov. Táto štúdia hodnotila online-video aktivitu, dospelých amerických používatel'ov internetu, ktorí zdiel'ajú resp. zverejňujú videá na svojich sociálnych profiloch. Podl'a štúdie sa počet takýchto užívatel'ov v posledných rokoch zdvojnásobil z pôvodných $33 \%$ na $72 \%$. Výsledky štúdie demonštruje graf na nasledujúcej strane.

Pri zdiel'aní virálneho obsahu však hrajú dôležitú úlohu aj sociálne siete, blogy a mikroblogy. Podl'a štúdie si $45 \%$ dospelých užívatel'ov internetu na sociálnych siet'ach videá prezerá a $22 \%$ ich aj zdiel'a. Pri rozdelení užívatel'ov do vekových skupín bolo zistené, že až 57 \% užívatel'ov vo veku od 18 do 49 rokov, na sociálnych siet'ach prezerá videá a $28 \%$ z nich videá aj zdiel'a. Vo vekovej skupine nad 50 rokov si videá prezerá len $26 \%$ a následne ich zdiel'a $11 \%$. [14] 


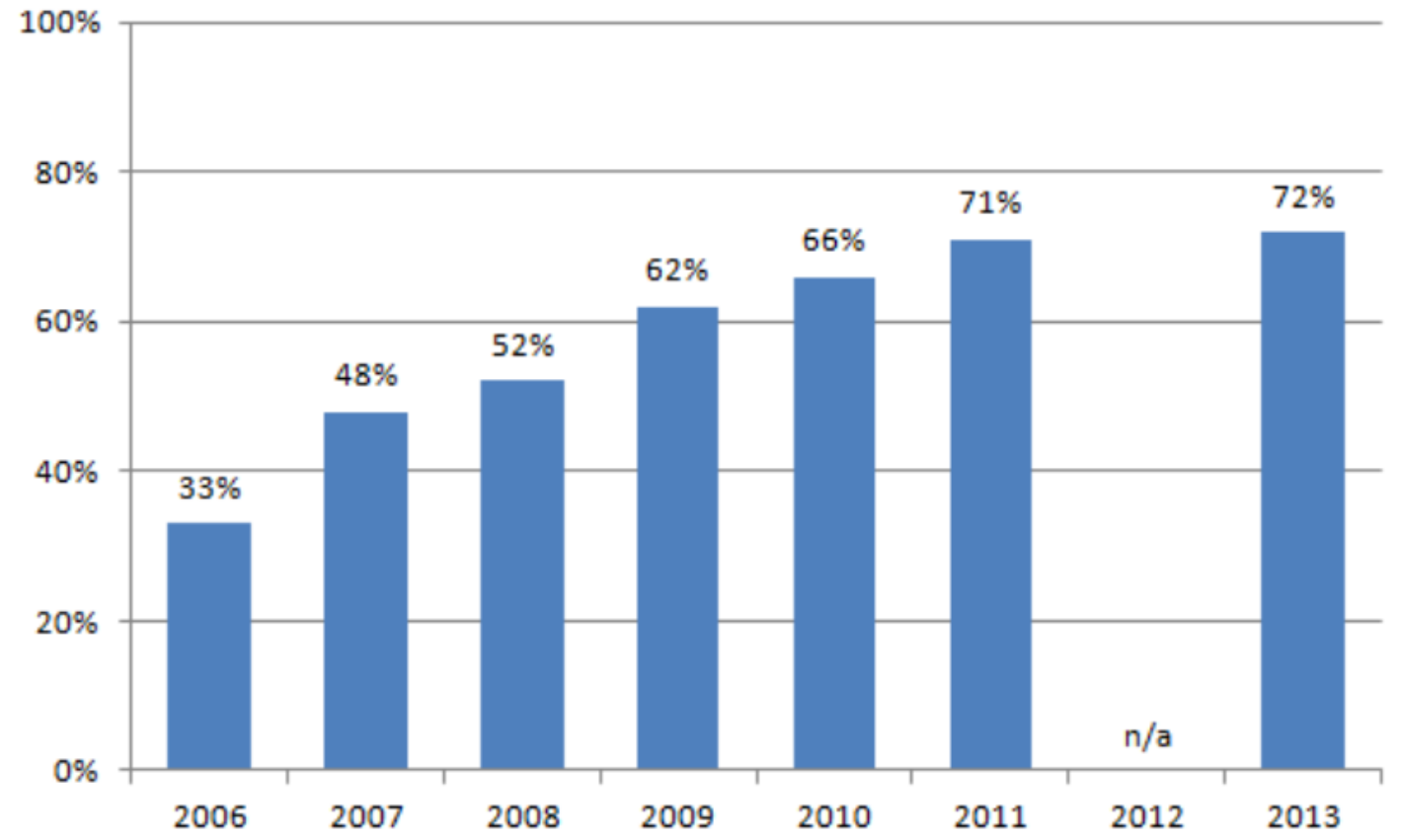

Obrázok 1. Zdiel'anie videí užívatel'mi v období rokov 2006 až 2013 - \% dospelých užívatel’ov internetu, ktorí zdiel'ajú videá (Zdroj: Pew Research Center. [online]. [cit. 2014-10-25]. Dostupné na: <http://marke tingland.com/study-number-of-people-who-share-or-post-online-videos-has-doubled-since-2009-61165>).

Americká štúdia uskutočnená spoločnost’ou Forrester Research formulovala nasledovné princípy úspešnej virálnej kampane:

- Humor: takmer $50 \%$ vírusových videí má prvky zábavy. $70 \%$ používatel’ov internetu, ktorí zdiel'ajú obsah potvrdilo, že tak robia z dôvodu, že je tento obsah smiešny a pobavil ich.

- Krátke videá: s rastúcou dížkou videí, strácajú internetoví diváci pozornost'. Podl’a prieskumov Forrester Research je optimálna priemerná dížka videa 01:42 minúty, pričom viac ako tretina úspešných videí trvala menej ako minútu. Platí však všeobecné odporúčanie, že dížka videa by nemala presiahnut' dve minúty.

- Známe osobnosti nie sú zárukou úspechu: bolo zistené, že len asi tretinu úspešných vírusových videí prezentovali celebrity. Zaintegrovanie celebrity do virálnej správy, nielenže zvyšuje náklady na jej tvorbu, ale súčasne to nie je ani zárukou úspechu.

- Sexi obsah nemusí byt' nutne najlepší: aj napriek mnohým predpokladom, ktoré by mohli virálne správy so šteklivým obsahom označovat' za pravdepodobne úspešné, je nutné spomenút' fakt, ktorý potvrdzuje opak - podl'a štúdie, bol sexi obsah prítomný v úspešných virálnych správach len v $16 \%$.

- Nezabudnút' do virálnej správy zakomponovat' značku: je nepochopitel'né ale aj prekvapivé, kol'ko firiem zabudne začlenit' svoju značku alebo produkt do inak úspešnej virálnej správy. Podl’a štúdie, až 55 \% virálnych videí, chýbal jasný odkaz na značku alebo produkt. [12]

Podl'a Slovenského centra Internetového marketingu (SCIM), sú pre úspešnú tvorbu virálnych správ, dôležité najme dve „,ingrediencie“:

- Revolučná myšlienka a jej dobré spracovanie: je potrebné vymysliet' originálnu myšlienku, ktorú l'udia ešte nevideli a technicky ju vhodne zhmotnit'. Pri tvorbe myšlienky je však potrebné dbat' na tematickú totožnost' virálnej správy s predmetom podnikania jej tvorcu. Príkladom môžu byt' videá resp. obrázky, v ktorých sú zobrazené rekordné výkony, ironické scénky, vtipné udalosti alebo naopak extrémne smutné udalosti. Ďalším príkladom 
môžu byt' hry nabádajúce ku kolektívnej interakcii, vzájomnému porovnávaniu a testom. V praxi sú často využívané nové technické vymoženosti internetu, ktoré umožňujú silnú personalizáciu prijímatel’a virálnej správy - prečítanie mena l’udským hlasom, prípadne zakomponovanie fotky prijímatel'a do virálnej správy.

- Technická kompatibilita a jednoduchá šíritel’nost': virálna správa, ktorá je doručená príjemcovi, musí byl' spustená jedným kliknutím, nakol'ko práve jedno kliknutie je maximálna akcia, ktorú je človek k šíreniu správy ochotný obetovat'. Užívatelia nezvyknú šírit' správy, pri ktorých je potrebné inštalovat' doplnkový softvér, prípadne hardvér na prezretie virálu. [13]

\section{Ciel' a metodika skúmania}

Ciel'om prieskumu bolo identifikovat' preferencie a hlavné atribúty virálnej správy, na základe ktorých by boli užívatelia internetu ochotní šírit' túto správu d’alej. Prieskum bol zameraný na segment mladých l'udí vo veku od 18 do 30 rokov, ktorí sú vd’aka sociálnym siet’am často vystavovaní mnohým reklamám. Pre účely prieskumu boli ako reprezentatívna vzorka tejto vekovej kategórie zvolení študenti Žilinskej univerzity v Žiline. Respondenti boli študenti všetkých stupňov dennej i externej formy štúdia na univerzite. Na dosiahnutie ciel'a prieskumu bola ako metóda zberu údajov použitá metóda dopytovanie a ako technika zberu údajov - elektronický dotazník, vytvorený prostredníctvom služby Googledocs, ktorý obsahoval dve identifikačné otázky zamerané na vek a pohlavie, štyri uzavreté a dve otvorené otázky, ktorých ciel'om bolo zistit' hlavé atribúty úspešnej virálnej správy. Návratnost' dotazníka predstavovala 235 odpovedí. Obdobie zberu údajov začalo 4.3.2014 a bolo ukončené 30.3.2014.

\section{Výsledky a diskusia}

$\mathrm{Na}$ vyplnení dotazníka participovalo $54 \%$ mužov a $46 \%$ žien. 73 \% respondentov spadalo do vekovej kategórie od 18 do 25 rokov. Menšou mierou bola zastúpená veková skupina od 26 do 30 rokov ( $24 \%$ ). $3 \%$ respondentov spadali do vekovej kategórie nad 30 rokov. K otázke akú formu správy užívatelia uprednostňujú, mali respondenti na výber dve možnosti a to obrázok alebo video. $\mathrm{Na}$ základe údajov získaných prostredníctvom sekundárneho prieskumu sa predpokladalo, že preferovanou formou virálu bude práve video. Tento predpoklad sa v rámci prieskumu potvrdil, nakol'ko až $76 \%$ respondentov uviedlo, že by uprednostnili virálnu správu vo forme videa. Medzi respondentmi sa našli však aj takí, ktorí preferujú ako virál skôr obrázok ako video (24\%).

Ďalšia otázka zist’ovala, aký faktor resp. atribút virálnej správy, vzbudzuje u príjemcu záujem a ochotu šírit' virál d'alej. Z údajov získaných zo sekundárneho prieskumu vyplynulo, že motivujúcim aspektom virálu bol v prevažnej miere humor. Výskum deklaroval, že takmer 50 \% vírusových videí je zábavných a 70 \% užívatel'ov internetu, ktorí jeho obsah zdiel'ajú to robia práve preto, že ich dané video pobavilo. Sekundárny výskum tiež ukázal, že iba $16 \%$ úspešných vírusových videí, ktoré boli do štúdie zaradené, obsahovalo sexi obsah. Primárny prieskum, zrealizovaný na vzorke 235 študentov Žilinskej univerzity sa však nie celkom stotožnil s vyššie uvedenými faktami. 44 \% respondentov uviedlo, že lákadlom pre šírenie virálnej správy je práve motív sexu a lásky. Takmer rovnakou, len o niečo nižšou percentuálnou mierou bol zastúpený už spomínaný aspekt humoru a zábavy (41\%). 15 \% respondentov by bolo ochotných šírit' správu s prvkami poučenia a rady.

Ciel'om d'alšej otázky bolo u vybranej vzorky respondentov identifikovat', aký typ aktérov by mal podl'a ich názoru vystupovat' v úspešnej virálnej správe (atraktívny muž/žena, milé zvieratká, známe osobnosti). Nadpolovičná väčšina (56 \%) opýtaných sa zhodla, že 
v úspešnej virálnej správe by mala vystupovat' atraktívna žena, či muž. Milé zvieratká, ako hlavných aktérov vo virálnej správe by chcelo vidiet' 35 \% opýtaných a známu osobnost' by vo virále uvítalo len $9 \%$ respondentov. Výsledky primárneho výskumu sa v tomto prípade zhodujú s tvrdením, ktoré deklaroval už spomínaný prieskum. Známe osobnosti teda nie sú v každom prípade zárukou úspešnej virálnej kampane, aj ked’ tretina skúmaných úspešných vírusových videí prezentovali celebrity.

Prieskum bol zameraný aj na zistenie preferovaného spôsobu šírenia správy. 69 \% študentov uviedlo, že by ako formu šírenia uvítali predovšetkým šírenie virálnej správy prostredníctvom sociálnych sietí, ako je napríklad Facebook. Samotný vznik sociálnych sietí spustil prílivovú vlnu, na ktorej sa virálny marketing celkom prirodzene vezie. Ludia sa radi podelia o to, čo sa im páči, o to čo ich šokovalo alebo akýmkol'vek spôsobom v nich vzbudilo záujem. Na sociálnych siet'ach sa to deje nenúteným a rýchlim spôsobom. Sírenie prostredníctvom multimediálnej siete YouTube uprednostňuje $26 \%$ študentov. Zvyšných $5 \%$ by virálnu správu bolo ochotných šírit' e-mailom. Vel'a l'udí si v súčasnosti myslí, že e-mail marketing už svoj čas slávy zažil a je prekonaný. Pravda je však taká, že je to stále jeden $\mathrm{z}$ najlepšie využitel'ných nástrojov virálneho marketingu a to najmä pre malých a stredných podnikatel'ov. Podmienkou je však aby firma dokázala odoslat' správu, ktorá pritiahne pozornost' ciel'ovej skupiny, bud' lákavou ponukou, zábavným obsahom, či relevantnými alebo šokujúcimi informáciami. Aj ked' e-mail ako spôsob šírenia správy, v dnešnej dobe, najmä medzi mladými prechádza do úzadia, jeho použitie dokáže stále zabezpečit' želanú odozvu.

Významný faktor, ktorý tiež určuje úspešnost' virálneho videa, je samotná jeho dížka. Prieskum zist'oval, akú maximálnu dížku videa sú príjemcovia schopný akceptovat' a video dopozerat' dokonca. Sekundárny výskum podl'a štúdie Forrester Research uvádza, že pre udržanie diváka v pozornosti, je potrebné video vtesnat' do intervalu 2 minút. Po tomto čase diváci začnú strácat' o video záujem. Priemerná dížka videí v štúdií bola 01:42 minúty a dokonca viac ako tretina trvala menej ako minútu. Výsledky primárneho prieskumu sa so štúdiou zhodujú. Až 38 \% študentov vyhovuje dížka videa v rozpätí 30 sekúnd až jednej minúty. $35 \%$ respondentov uviedlo, že sú schopní akceptovat' dížku videa maximálne do dvoch minút. $25 \%$ opýtaných by neakceptovalo dížku trvania dlhšiu ako 30 sekúnd a len $2 \%$ by si video pozreli aj v prípade, že by jeho dĺžka presiahla dve minúty.

Pre virálnu správu je samošíritel'nost' najdôležitejším predpokladom pre úspech. Posledná otázka prieskumu teda zist'ovala, či respondenti majú tendenciu zaujímavú správu šírit' d'alej. $38 \%$ respondentov uviedlo, že správu, ktorá sa im páči skôr zdiel'ajú ako nezdiel'ajú. O niečo menej študentov (30\%) hodnotný obsah virálnej správy jednoznačne zdiel'a. Z týchto zistení je teda možné vyvodit' záver, že až $68 \%$ študentov zvykne správu šírit' d'alej. $20 \%$ študentov vyjadrilo názor, že skôr virálny obsah nezdiel'ajú a iba $12 \%$ opýtaných nezdiel'a virálny obsah vôbec. Podl'a americkej štúdie z Pew Research Center, až $71 \%$ účastníkov prieskumu zdiel'a videá na sociálnych siet’ach. Percentá získané z primárneho aj sekundárneho výskumu sú v tomto prípade takmer totožné.

Podl'a výsledkov prieskumu, zrealizovaného na študentoch Žilinskej univerzity by mala mat' virálna správa nasledujúce atribúty - malo by íst' o video s dížkou trvania maximálne jednu minútu, $v$ ktorom bude hlavným motívom láska a sex, resp. humor (nakol'ko obe kategórie boli dostatočne percentuálne zastúpené) a hlavným aktérom by mal byt' atraktívny muž resp. atraktívna žena. [14]

\section{Záver}

Každá reklama by mala byt' taká dobrá, aby u spotrebitel'a vzbudila nielen chut' nakupovat', ale aj chut' podelit' sa o zážitok z nej. Virálny marketing len potvrdzuje, že 
reklama s kvalitným obsahom má potenciál byt' úspešná a zasiahnut' čo najväčší počet prijímatel'ov jej posolstva. .

\section{Literatúra}

[1] RUSHKOFF, D.: Media virus!: Hidden agendas in popular culture. New York: Ballantine Books, 1996. str. 31. ISBN 03-453-977-46.

[2] Jurvetson, S. - Draper, T.: Viral Marketing. [online] 1.1.1997. [cit. 29.1.2010]. Dostupné na internete: http://www.dfj.com/news/article_26.shtml

[3] Vírusový, či virálny marketing. [online]. [cit. 2013-11.02]. Dostupné na internete: < http://www.wesolyaniolek.com/virusovy-ci-viralny-marketing/>.

[4] Virálny obsah na stránkach. [online]. [cit. 2013-11.01]. Dostupné na internete. <http://www.elet.sk/?seo-optimalizacia-1\&sprava=viralny-obsah-na-strankach>.

[5] KOTLER, P. Marketing v pohybu. Praha: Management Press, s.r.o.2007. 99 s. ISBN 978-80-7261-161-4.

[6] SCOTT, D. The Advanced Dictionary of Marketing. London:OUP Oxford, 2007. 167 s. ISBN 9780199286003.

[7] Godin, S.: Unleashing the Ideavirus. Chicago: Dearborn Trade Publishing, 2000. str. 1332 ISBN 97-807-868-8717-0.

[8] Online marketing. [online]. [cit. 2013-11.02]. Dostupné na internete: $<$ http://www. lundegaard.eu/sk/interactive/sluzby/on-line-marketing/viralnimarketin>.

[9] Virálny marketing. [online]. [cit. 2013-11.02]. Dostupné na internete: $<$ http://digitalmag.sk/viralny-marketing/>.

[10] RIPLOVÁ, K. (2006). Využitie viral marketingu ako účinného nástroja marketingovej komunikácie. In: Nové trendy marketingu. Trnava: Fakulta masmediálnej komunikácie Univerzity sv. Cyrila a Metoda v Trnave, str. 156.

[11] Hnonline. [online]. [cit. 2013-11.02]. Dostupné na internete: <http://moje. hnonline.sk/node/4638>.

[12] Tvorba virálneho obsahu. [online]. [cit. 2014-13.03]. Dostupné na internete: $<$ http://www.searchenginejournal.com/creating-viral-video-content-aresearchstudy/28886/>.

[13] Tajomstvá internet marketingu. [online]. [cit. 2014-05.04]. Dostupné na internete: <http://www.atrixmedia.com/viralny_marketing.html>.

[14] GREGOVÁ, S.: Virálny marketing, diplomová práca, 2014. Žilinská univerzita v Žiline 